Jerzy MACEWICZ*

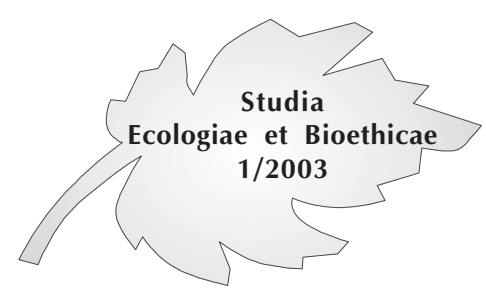

\title{
Czy inżynieria genetyczna? - za i przeciw modyfikowaniu naszej żywności
}

Dyskusja o inżynierii genetycznej wtargnęła do mass mediów Unii Europejskiej i USA. Opinia publiczna dała wyraz dezaprobaty gdy naukowcy zaczęli radykalnie zmieniać cechy wszystkiego czym się odżywiamy. Potrafią już wyposażać rośliny i zwierzęta, które zjadamy - w nowe, obce dla nich geny. Takich udoskonalonych roślin i zwierząt nigdy dotąd w przyrodzie nie było! Polska opinia publiczna będzie jeszcze długo w nurcie dyskusji na ten temat.

Jednak ani opinia publiczna, ani ustawodawstwo Unii Europejskiej i Polski nie będą nadążały za burzliwym rozwojem biotechnologii spożywczej. Wiele osób nie rozumie podstawowych pojęć z tej dziedziny. Jest ważne, aby studenci zdawali sobie sprawę z zagrożeń i korzyści jakie przyniesie wprowadzana do powszechnego użytku żywność zmodyfikowana metodami inżynierii genetycznej.

Studenci powinni brać udział w dialogu z argumentami zwolenników i przeciwników genetycznego modyfikowania żywności. Powinni podejmować próby oceny ryzyka związanego z jej konsumpcją ale też znać perspektywy poprawy jakości żywności po modyfikacji. Podstawowym celem edukacji jest prezentacja osiągnięć, szans i ryzyka jakie niesie genetyczna modyfikacja żywności.

$\mathrm{W}$ wyniku edukacji w tym zakresie, studenci powinni dysponować wiedzą o:

1) komercyjnie dostępnych, genetycznie zmodyfikowanych produktach spożywczych a także zmodyfikowanych komponentach stosowanych w produkcji piwa, chleba, jogurtów, o obowiązkowym ich „znakowaniu" w handlu detalicznym,

2) opinii ekspertów na temat ewentualnego przedostania się nowych niekorzystnych kombinacji genów do bakterii jelitowych człowieka a także do środowiska naturalnego,

3) możliwości konsumpcji ludzkich genów wprowadzanych do roślin,

4) skutkach ubocznych spożywania transgenicznych roślin i zwierząt dla zdrowia przyszłych pokoleń.

\footnotetext{
* Instytut Ekologii i Bioetyki UKSW w Warszawie.
} 
5) wynikach badania opinii publicznej i postawie organizacji ekologicznych.

UKSW:

Oto proponowana treść wykładów na wydziale Ochrony Środowiska

- Stare odmiany jabłek i rasy krów - to przykłady wczesnych ingerencji genetycznych dokonywanych już przez człowieka.

- Definicje roślin i zwierząt transgenicznych.

- Produkcja żywności oparta na genetycznie zmodyfikowanych drożdżach i bakteriach: pieczywo, sery, kefiry, kiszonki, salami itp.

- Wprowadzanie nowych genów do roślin i zwierząt - technika modyfikacji genetycznych.

- Przykłady roślin uprawnych zmodyfikowanych genetycznie: pomidor, ziemniak, soja, rzepak, kukurydza itd.

- Przykłady najczęściej modyfikowanych cech roślin: wartości odżywcze i użytkowe.

- Korzyści dla przemysłu spożywczego wynikające ze stosowania roślin genetycznie zmodyfikowanych.

- Czy manipulacje genetyczne w żywności są bezpieczne dla konsumenta?

- Zagrożenia związane $\mathrm{z}$ wykorzystaniem inżynierii genetycznej $\mathrm{w}$ żywności.

- Czy rozwój rolnictwa ekologicznego umożliwi odstąpienie od manipulacji genetycznych w żywności?

- Opinia publiczna Polski i Unii Europejskiej wobec żywności genetycznie modyfikowanej.

- Argumenty zwolenników i przeciwników obowiązkowego znakowania zmodyfikowanej żywności.

- Regulacje prawne dotyczące żywności genetycznie zmodyfikowanej, jej importu i znakowania.

- Polski projekt Programu Bezpieczeństwa Biologicznego Żywności.

Genetycznie zmodyfikowana nowa żywność wywołuje skrajne reakcje: od hurraoptymizmu po zaciekły sprzeciw. Podczas gdy entuzjaści inżynierii genetycznej przedstawiają wielkie możliwości, sceptycy wskazują na zagrożenia dla nas i dla przyszłych pokoleń. Ryzyko związane z genetycznymi manipulacjami w żywności - jest nadal nieokreślone ! A skutki manipulacji będą nieodwołalne i trwałe!

Obecnie już 1/3 uprawianej w świecie kukurydzy - jest genetycznie zmodyfikowana. Zmodyfikowana jest ponad połowa uprawianej soi. Użyto tu genów z bakterii, z wirusa kalafiorów i z petunii. Większość przetwarzanej przemysłowo żywności zawiera komponenty zmodyfikowane genetycznie. 
Już dzisiaj niemal wszyscy odżywiamy się genetycznie zmienionymi produktami. Około 60 \% produktów spożywczych na półkach supermarketów USA i Europy zawiera zmodyfikowaną kukurydzę, rzepak, soję... A w $100 \mathrm{~kg}$ szynki wieprzowej znajduje się $4 \mathrm{~kg}$ białka sojowego. Białko zmodyfikowanej soi używane jest też do produkcji 70\% wędzonek i kiełbas w Polsce...

Autorami jadłospisów stają się w coraz większym stopniu biotechnolodzy. Okiem i podniebieniem nie odróżnimy nowego pokarmu od tradycyjnego. Nie odróżnimy pomidorów, które po manipulacji genetycznej nie miękną, nowego ryżu wzbogaconego o gen tworzący witaminę $\mathrm{A}$. Także szybko rosnący łosoś, podrasowany nowym genem (pobranym z innych ryb) powodującym syntezę hormonu wzrostu - smakuje tak jak tradycyjny.

Dzisiaj korzyści finansowe płyną głównie do ponadnarodowych koncernów biotechnologicznych. A to dlatego, że wytworzyły one i eksportują np. ziarno "super roślin” odpornych na choroby, na szkodniki i na chemikalia do zwalczania chwastów, wytworzyły ogórki ze zwiększoną ilością białka oraz nie brunatniejące ziemniaki. Czy koncerny zrezygnuja z zysków? Nie zrezygnują!

Ale czy żywność tak zmodyfikowana jest bezpieczna? Przenoszenie obcych genów od całkowicie niespokrewnionych organizmów (np. szczurzych do sałaty - by wytwarzała vitaminę C) może spowodować zaburzenia w działaniu tych genów lub genów macierzystych. A to może mieć nieprzewidziane skutki zdrowotne. Na przykład alergenność czy toksyczność. Stwierdzono już wymieranie larw motyli czy patologie u zwierząt doświadczalnych karmionych zmodyfikowanymi roślinami. Zwolennicy i przeciwnicy modyfikacji zgadzają się co do jednego: metody modyfikacji są jeszcze w powijakach.

Czy zatem żywność, która powstaje dzięki inżynierii genetycznej powinna być tworzona? Czy powinna być specjalnie oznakowana? Czy konsument powinien mieć prawo wyboru? Czy żywność taka może być stosowana $\mathrm{w}$ zbiorowym żywieniu? Pod naciskiem opinii publicznej, Unia Europejska w tworzonym ustawodawstwie dotyczącym nowej żywności, wymaga aby każda modyfikacja uzyskała indywidualną akceptację Komisji a tworzone produkty spożywcze były specjalnie oznakowane.

Posłuchajmy argumentów biotechnologów i ich zagorzałych przeciwników - ekologów. Najpierw argumenty przemawiające ZA tworzeniem nowej żywności:

1) genetycznej modyfikacji podlega mniej niż jeden promil materiału genetycznego wybranego gatunku,

2) geny wprowadzane do roślin są całkowicie trawione przez nasz przewód pokarmowy, 
3) nowe substancje produkowane przez rośliny transgeniczne są identyczne z produkowanymi przez normalne rośliny,

4) wniesienie genetycznej odporności na środki ochrony roślin sprawi, że na plantacjach aż o $30 \%$ zmniejszy się ilość stosowanych chemikaliów a to spowoduje zasadniczy postęp w ochronie środowiska,

5) żywność transgeniczna jest sposobem na pokonanie głodu na Ziemi: zmodyfikowane rośliny będą mogły wegetować na terenach dotąd zbyt suchych lub zasolonych, stając się ratunkiem dla ludności Trzeciego Świata,

6) podobnie jak to miało miejsce $\mathrm{z}$ akceptacją $\mathrm{np}$. $\mathrm{z}$ przeszczepiania narządów - wydaje się że od inżynierii genetycznej w żywności nie ma odwrotu,

7) po skrzyżowaniu żyta z pszenicą - sztucznie otrzymane "pszenżyto” uprawiane jest obecnie na całym świecie, na rosnącym areale,

8) zagrożenia są wyolbrzymiane przez naukowców z odległych od genetyki dyscyplin, zazdrosnych o sukcesy genetyków - a przecie nikt nie żąda likwidacji medycyny mimo że ingeruje ona $\mathrm{w}$ naturalny porządek...

A teraz argumenty PRRZECIW modyfikacjom:

1) inżynieria genetyczna łamie dotychczas surowo przestrzeganą barierę międzygatunkową, tworząc sztuczne kombinacje genów, które nigdy nie miałyby szans zaistnieć $\mathrm{w}$ naturze,

2) umiemy modyfikować organizmy roślin i zwierząt jedynie w bardzo prymitywny sposób a przecie organizmy te w wyniku samoreplikacji będą powielać się $\mathrm{w}$ nieskończoność, zatem skutki takich zabiegów będą dla środowiska nieodwracalne i trwałe,

3) geny wprowadzone do roślin będą następnie przenoszone na inne organizmy poprzez np. mszyce lub gryzonie, a nie wiemy jak uporządkować środowisko po takim wypadku,

4) nowy organizm nie posiada naturalnego siedliska, może zatem zaburzyć równowagę ekologiczną swego ekosystemu a niewiele wiemy o długofalowych konsekwencjach takich procedur,

5) co się stanie jeśli do bakterii jelitowej człowieka dostanie się kombinacja genów, które uczynią z niej szczep zjadliwy, wywołujący śmiertelną chorobę zakaźną?

6) jeżeli daje się manipulować genami z taką łatwością, co stanie się gdy nieodpowiedzialni naukowcy podejmą pracę z genami bakterii i wirusów powodujących groźne epidemie?

7) dojdzie do konsumpcji ludzkich genów wniesionych np. do ryb lub zwierząt hodowlanych,

8) czy nie byłoby lepiej skoncentrować się na technikach pozwalających na potrojenie tradycyjnych plonów? 
9) choć święte prawo poznania nie podlega ocenie etycznej to wykorzystanie poznanego do określonych celów - wymaga poddania stosowanej procedury ocenie etycznej,

10) manipulacje genetyczne prowadzą nas na obszary, które powinny być pozostawione Bogu.

\section{Literatura proponowana:}

McHugen A., 2003 - Żywność genetycznie zmodyfikowana, Tłum. z ang. BABuchowski A., Seria „Żywność, Technologia i jakość”.

KRUSZEWSKA I., 1996 - Bawiqc się w Pana Boga, Manipulowana genetycznie żywność $w$ Europie Środkowo-Wschodniej, Greenpeace International. Federacja Zielonych - Kraków.

LuDwICKI J. K., 1999 - Ryzyko zastosowania GMO w żywności, w: materiały z Konferencji naukowej pt. Ocena ryzyka związana z uwolnieniem GMO do środowiska, Radzików.

DUBERT F., Inżynieria genetyczna roślin uprawnych, „Nauka” 4/1999.

Twardowski T., Michalska A., 1998 - Genetycznie modyfikowane organizmy (GMO) a środowisko, Poznań.

Twardowski T., 1997 - Rozwój biotechnologii. Projekt rozwiq̨ań prawnych dotyczq̨cych stosowania genetycznie modyfikowanych organizmów, Poznań.

BeDnARski W., Repsa A., (red.) 2001 - Biotechnologia żywności, Wydawnictwo Naukowo-techniczne, Warszawa.

\section{Genetic engineering - yes or no for modification of our food}

\section{SUMMARY}

The discussion about genetic engineering became present in mass media in UE and USA. Scientists didn't meet with public opinion's approval, when they started changing radically the food that we consume.

But neither public opinion nor UE or Polish legislation keeps pace with great development of food biotechnology.

Students should take part in a dialog with arguments of supporters and opponents of GM food. The main goal of this education is to show achievements, chances, perspectives and risks connected with GM food.

As results of this education students should have the knowledge about issues presented in the article, which also includes the content of lectures in Faculty of the Environmental Protection in UKSW.

GM food is causing extreme reaction: from absolute optimism to fierce opposition. While enthusiasts are showing large, unprecedented possibilities, skeptics remind about danger for us and future generations. Risk connected with GM food is still unknown. And effects of manipulations will be irrevocable and lasting.

Then there is a chance to hear arguments of biotechnologists and their fierce adversaries ecologists. 